\title{
The Experience of Social Support and Role Conflict Among Career Women in Klang Valley
}

Siti Marziah Zakaria, Abdul Salam Yussof, Mohamad Mohsin Mohamad Said \& Zarina Othman

To Link this Article: http://dx.doi.org/10.6007/IJARBSS/v12-i1/11747

DOI:10.6007/IJARBSS/v12-i1/11747

Received: 07 November 2021, Revised: 11 December 2021, Accepted: 25 December 2021

Published Online: 05 January 2022

In-Text Citation: (Zakaria et al., 2022)

To Cite this Article: Zakaria, S. M., Yussof, A. S., Said, M. M. M., \& Othman, Z. (2022). The Experience of Social Support and Role Conflict Among Career Women in Klang Valley. International Journal of Academic Research in Business and Social Sciences, 12(1), 41-54.

Copyright: (c) 2022 The Author(s)

Published by Human Resource Management Academic Research Society (www.hrmars.com)

This article is published under the Creative Commons Attribution (CC BY 4.0) license. Anyone may reproduce, distribute, translate and create derivative works of this article (for both commercial and non0-commercial purposes), subject to full attribution to the original publication and authors. The full terms of this license may be seen

at: http://creativecommons.org/licences/by/4.0/legalcode

Vol. 12, No. 1, 2022, Pg. $41-54$

Full Terms \& Conditions of access and use can be found at http://hrmars.com/index.php/pages/detail/publication-ethics 


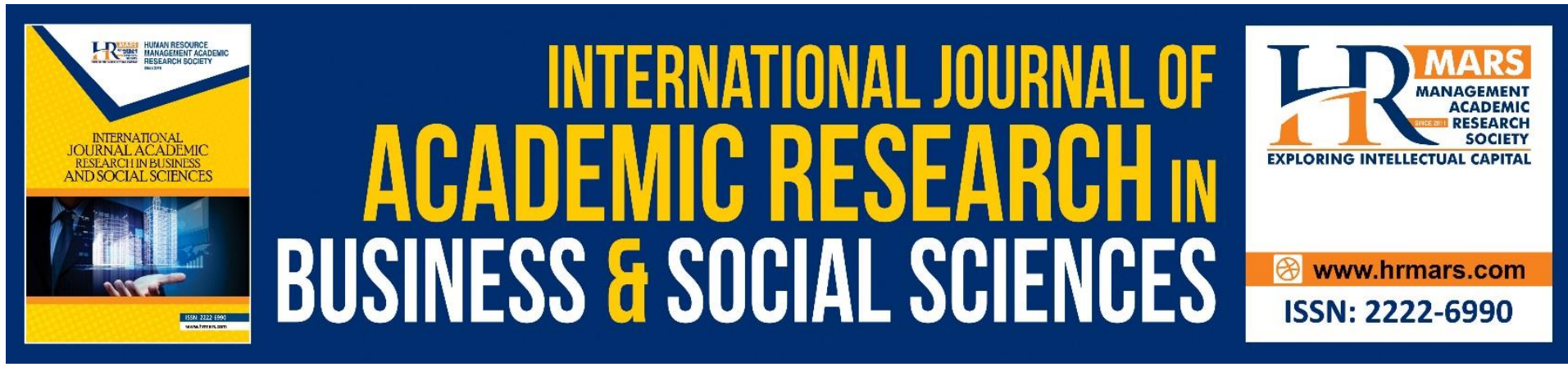

\title{
The Experience of Social Support and Role Conflict Among Career Women in Klang Valley
}

\author{
Siti Marziah Zakaria, Abdul Salam Yussof, Mohamad Mohsin \\ Mohamad Said \& Zarina Othman \\ Universiti Kebangsaan Malaysia \\ Email: marziah@ukm.edu.my
}

\begin{abstract}
Most married women who are working may face several challenges in life. These women face conflicting roles as employees, wives, and mothers; all at the same time. Previous studies tend to focus on managing role conflicts, the stress of working mothers, the psychological impact on working mothers, and the impact on children when both parents are working. To a certain extent, these studies are still not comprehensive enough to identify (i) the level of role conflict (ii) how working mothers manage stress and (iii) the mental health level of mothers who struggle to strike a balance between work and family. This paper will present the perceptions of social support and role conflict experienced by working women. This study was conducted quantitatively through questionnaires. A total of $\mathbf{2 8 3}$ women in Klang Valley, Malaysia were selected through purposive sampling. The questionnaire utilizes the Multidimensional Scale of Perceived Social Support (MPSS) and Work-Family Conflict Instrument (WFCI). The results revealed that about $80-90 \%$ of the working women agreed they experienced various forms of role conflict that negatively affected their well-being. In terms of social support, respondents admitted they received more support from their families than friends. Respondents' perceptions of the availability of support are at a satisfactory level. However, they reported high level of role conflict in the family. Most of the times, they need to sacrifice family welfare to fulfill job demands. This situation may lead to intense pressure and mental health issues. Career women in Klang Valley need flexibility in term of working hours. The employers need to be sensitive of the role conflict of female workers who have young children, sick parents, and disabled or special need children. Employers, communities, and governmental agencies may offer support to career women with multiple responsibilities to uplift their psychological well-being.
\end{abstract}

Keywords: Working Women, Emotional Well-Being, Social Support, Role Conflict

\section{Introduction}

The issue of work and family balance has become an important agenda in governmental and non-governmental organizations. Balancing responsibilities as an employee and a mother or a wife is the biggest challenge for most working women in Kuala Lumpur (the capital city of Malaysia). As a developing country, Malaysia 
experiences various demographic, social and economic changes. Changes in these aspects alter the current situation in family life (Lapierre-Adamcyk et al., 2006). These changes have contributed to a shift in gender roles, consequently encouraging more women to participate in the labour market, and further changing the domestic job distribution (Tezli \& Gauthier, 2009).

Women in the Klang Valley, especially those who are married, may have chosen to work to help with the family income. In big cities, especially Kuala Lumpur, the phenomenon of working women has become a norm. Women's participation in the job market has been increasing every year (Luffman, 2006). The number of married women in the job market is also rising, despite these women having young children. The female labour force in February 2021 increased by 2.7 thousand people to 6.23 million people compared to January 2021 (Department of Statistics Malaysia, 2021). Most of them work in the manufacturing, trade, education, agriculture, and public administration sectors.

Women's participation in the labour market has also increased from $55.2 \%$ in 2018 to 55.6\% in 2019. In 2019, 1536200 women in Selangor joined the labour market, compared to 1953300 men. They served as employers, employees, self-employed or unpaid family workers (Department of Statistics Malaysia, 2020). Their ages ranged from 15 to 64 years old. In Selangor, 355800 working women held professional positions, compared to only 283900 male professionals.

Previous studies have contributed a lot to the treasure trove of references about working women. Many have focused on managing role conflict, the stress of working mothers, the psychological impact on working mothers, and the impact on children when both parents are working (Sumra \& Schillaci, 2015; Janzen \& Muhajarine, 2003). These studies, however, are not comprehensive enough to delve further into identifying the level of role conflict. Less attention given to how working mothers manage stress and the mental health level of mothers who struggle to strike a balance between work and family. Research on this issue is very vital to ensure the well-being of Malaysian women. The well-being of parents will thus contribute to the happiness of young children, teenagers, and adults.

Previous studies have shown that working women bear more burden in household and family management than their husbands. Caring for children, especially the young ones, is often the wife's essential duty (Hays, 1996). Besides that, women also shoulder the substantial task of managing household affairs (Sumra \& Schillaci, 2015). Thus, this scenario may trigger stress among working mothers. The uncooperative and uncaring attitude of their husbands will worsen the emotional and physical health of working mothers. The condition will be more chronic if working mothers are unwell, undergoing maternal abstinence, or undergoing medical treatment.

Findings from several previous studies also shown that women often sacrificed their career advancement by turning down promotions, switching jobs, and working in shorter periods; they were worried about being unable to focus their attention on their families (Lapierre-Adamcyk et al., 2006). As responsibilities in the workplace increase, the stresses and conflicts women face also rise. The situation gets worse when they have children aged six years old and below. Lack of social support will induce various symptoms of mental illness such as insomnia, poor appetite, anxiety, and depression (Alex, 2015). A study conducted in New York showed that several women chose not to 
have children or postponed the desire to have children as they were worried about being unable to focus on their families. Lately, this scenario has also occurred in Malaysia, where the number of children born and raised by working women is declining. Many working women have one child only or two children at the most.

Therefore, this article will analyse the perceptions of social support and role conflict experienced by working women in the Klang Valley. Social support and role conflict are indicators of emotional well-being. Thus, to improve women's emotional well-being, those two elements must be evaluated. Information on these psychological elements will increase the awareness of all parties on the well-being of working women. It will pave the way for better support for working women in their contribution to achieving national prosperity.

\section{Literature Review}

Social support is very important and needed by every individual including working women. Usually, working women hope to get social supports from those close to them, such as spouses, family members, and friends. Zakaria et al. (2016) have studied the influence of job satisfaction and social support on the life satisfaction of working women. A total of 234 female respondents who met the criteria were selected to answer questionnaires on life satisfaction by Barrett and Murk (Life Satisfaction IndexShort Form, 2006); social support by Zimet et al (Multidimensional Scale of Perceived Social Support, 1988); and career satisfaction by MacDonald and Maclntyre (The Generic Job Satisfaction Scale, 1997).

The study discovered that middle-aged women who worked and lived in Kelantan did not get sufficient or satisfactory social support from their peers. Lack of social support referred to the emotional aspect where they could not share their sadness and joy due to not having many friends. The respondents also felt that they could not expect any support from their peers whenever they faced problems (Zakaria et al., 2016). Social support received from friends is very important and meaningful for working women. They can exchange opinions and advice, and provide emotional and moral strength, more so when affected by family, work, or personal problems.

Noor (1999) studied the relationship between work-family role conflict and well-being. Most respondents work because of economic needs and personal interests, and the need to work after graduation. However, a busy work schedule has forced these working women to leave their children in the care of others while they work. They feel guilty because of the lack of time, love, and attention they give to their children. The feeling of guilt reflects the lack of emotional well-being experienced by those working women. It becomes more chronic when the spouse does not play the role of a father and a husband at all in the home and fail to provide emotional support to the wife, besides problems caused by in-laws (Ahrens \& Ryff, 2006).

Previous studies have shown that role conflicts both at home and in the workplace influence working women (Sumra \& Schillaci, 2015; Alex, 2015). Problems that plague them at work can cause them to become irritable at home. Most respondents agreed that they faced more problems in the workplace compared to marital and family issues. Nevertheless, marital and family conflicts will cause more devastating psychological stress on them. Many female respondents prefer family over their jobs, which explains why these working women do not neglect household chores 
such as tending children and husbands and doing housework. Social support and help from spouses will reduce the stress or fatigue caused by fulfilling the roles of mother and worker simultaneously.

In addition to hoping for support from spouses and family members, most women use religion as a coping mechanism or coping strategy when experiencing stress. Like several previous studies, religion is a coping mechanism for an individual who is in an uncontrollable, unmanageable, and troubled state (Williams et al., 1991). In short, although working women have various roles such as employees, mothers, children, and wives, they still perform their responsibilities well. Working women will also be looking for coping strategies to reduce their stress levels in achieving emotional well-being. Ibrahim and Ramli (2021) conducted another study in Putrajaya on work-family conflict among female civil servants. The objective of this study was to identify the level of work-family conflict and examine the relationship of work-related, family, individual and financial factors with work-family conflict among civil servants in Putrajaya. A total of 274 civil servants aged from 26 to 41 years old and above have agreed to be the respondents of this study after questionnaires were distributed online and through hand delivery to 384 civil servants. A simple random sampling method has been used to select the study sample.

Results of the quantitative study showed that most of respondents agreed with the statement that work in the office demanded a lot of their time, energy, and attention, followed by the fact they were assigned a lot of work at the office. Being busy at the office caused those respondents to have the tendency to feel tired and faced difficulties in carrying out their roles as wives, mothers, and daughters at home; thus, leading to work-family conflict (Ibrahim \& Ramli, 2021). Respondents working in the management and professional group experienced higher work-family conflict than those in the support group. This finding suggests that higher-ranking employees are at higher risk of experiencing work-family conflict than lower-ranking ones.

Moreover, the study also proves that respondents with higher levels of education, such as bachelor's degree and postgraduate degree, experience a greater degree of workfamily conflict than those who possess Sijil Pelajaran Malaysia (SPM) qualification. Similarly, respondents with a higher monthly income of RM4501 to RM5501 and above experienced a greater degree of work-family conflict than those with a monthly earning of around RM1000 to RM2500 (Ibrahim \& Ramli, 2021). Thus, the high level of education and income did not prevent the respondents from experiencing work-family conflict and the conflict was more challenging.

\section{Methodology}

This study involved 283 respondents around Kuala Lumpur and Selangor using the purposive sampling method. Several criteria were set as conditions to be met by the study sample. The researchers have established inclusive criteria such as women working in the Klang Valley, aged between 20 to 60 years old only, Malaysian citizens, married and have children, and living with spouses and children. Then, the questionnaires were distributed to the study sample that met the criteria set for the study.

The questionnaire covered demographics, perceptions of social support using a measurement tool developed by Zimet and his colleagues, the Multidimensional Scale of Perceived Social Support (MSPSS), and Work-Family Conflict Instrument (WFCl), the 
measurement of role conflict using a measurement tool developed by the researchers. MSPSS covers 12 items in total. Respondents had to indicate their level of agreement on a given statement with a 4-point Likert scale, namely $1=$ strongly disagree, $2=$ disagree, 3 = agree, and 4 = strongly agree (Zimet et al., 1988).

The role conflict scale measures the role conflict experienced by the respondents as wives, mothers, and employees in their workplaces. The researchers developed all the items, while experts in this field validated the contents of those 16 items. The measurement of this section used a 4-point Likert scale ( 1 = strongly disagree, $2=$ disagree, 3 = agree and 4 = strongly agree). The role conflict scale was constructed to examine how working women adapt themselves in 3 different roles, namely as wives, mothers, and employees.

It took the researchers three (3) months to collect the study data. Data were then analysed using SPSS software. Descriptive analysis has been performed on the data, focusing on mean, standard deviation, frequency, and percentage.

\section{Study Findings}

Descriptive analysis was performed on the data to find patterns of agreement on statements related to social support and role conflict. These two elements or constructs have gone through the validation and reliability process before being distributed to the respondents. Factor analysis performed on the items found that the construct of social support can be divided into three (3) domains, namely peer support, family support, and support availability. Peer support was measured from items B4, B5, B7, and B10. Furthermore, family support was measured from items B2, B6, B9, and B12. Finally, support availability was measured from items B1, B3, B8, and B11.

Some examples of items for the peer support domain are: "My friends do their best to help when I am in need", "I can count on my friends if there is any problem." An analysis of domains and items showed that respondents received good support from their peers. Item B4 showed a high percentage $(88.3 \%)$ of respondents agreed that friends strived to help them when in need. Whereas $83 \%$ agreed that they could count on their friends if they have problems. Most of them also agreed that they have friends to share their sorrows and joys.

For the family support domain, an example of the item is "I can talk to my family about my problems". An analysis of that item found that $83.4 \%$ of the respondents agreed that they could talk about problems they faced to their families. A large number (92.3\%) admitted that they received emotional support from their families. Their families were also said to be willing to help them in making decisions. They also reported that their families tried their best to help them.

The support availability domain also showed consistent findings by having a high percentage at the level of agreement. Majority of respondents agreed that they have someone who were always with them in times of need. They also admitted that some individuals cared about their feelings (87.9\%), and they have someone to share their happiness and grief (85.2\%). This finding indicates a good perception of the level of availability of support. Most of respondents expressed their agreement in all items related to the availability of support (refer to Table 1 ). 
Table 1. The descriptive analysis of social support

\begin{tabular}{|c|c|c|c|c|c|}
\hline No & Items & $\begin{array}{l}\text { Strongly } \\
\text { disagree }\end{array}$ & Disagree & Agree & $\begin{array}{c}\text { Strongly } \\
\text { agree }\end{array}$ \\
\hline & $\begin{array}{l}\text { Domain: } \\
\text { Peer } \\
\text { support }\end{array}$ & & & & \\
\hline B4 & $\begin{array}{l}\text { My friends } \\
\text { do their } \\
\text { best to help } \\
\text { when I am } \\
\text { in need. } \\
\text { I can count }\end{array}$ & $\begin{array}{c}5 \\
(1.8 \%)\end{array}$ & $\begin{array}{c}28 \\
(9.9 \%)\end{array}$ & $\begin{array}{c}162 \\
(57.2 \%)\end{array}$ & $\begin{array}{c}88 \\
(31.1 \%)\end{array}$ \\
\hline B5 & $\begin{array}{l}\text { on my } \\
\text { friends if } \\
\text { there is any } \\
\text { problem. } \\
\text { I have }\end{array}$ & $\begin{array}{c}13 \\
(4.6 \%)\end{array}$ & $\begin{array}{c}35 \\
(12.4 \%)\end{array}$ & $\begin{array}{c}160 \\
(56.5 \%)\end{array}$ & $\begin{array}{c}75 \\
(26.5 \%)\end{array}$ \\
\hline B7 & $\begin{array}{l}\text { friends with } \\
\text { whom I can } \\
\text { share my } \\
\text { joys and } \\
\text { sorrows. }\end{array}$ & $\begin{array}{c}8 \\
(2.8 \%)\end{array}$ & $\begin{array}{c}26 \\
(9.2 \%)\end{array}$ & $\begin{array}{c}144 \\
(50.9 \%)\end{array}$ & $\begin{array}{c}105 \\
(37.1 \%)\end{array}$ \\
\hline B10 & $\begin{array}{l}\text { I can talk to } \\
\text { my friends } \\
\text { about my } \\
\text { problems. }\end{array}$ & $\begin{array}{c}9 \\
(3.2 \%)\end{array}$ & $\begin{array}{c}56 \\
(19.8 \%)\end{array}$ & $\begin{array}{c}145 \\
(51.2 \%)\end{array}$ & $\begin{array}{c}73 \\
(25.8 \%)\end{array}$ \\
\hline & $\begin{array}{l}\text { Domain: } \\
\text { Family } \\
\text { support }\end{array}$ & & & & \\
\hline B2 & $\begin{array}{l}\text { I am getting } \\
\text { emotional } \\
\text { support } \\
\text { from my } \\
\text { family. }\end{array}$ & $\begin{array}{c}6 \\
(2.1 \%)\end{array}$ & $\begin{array}{c}16 \\
(5.7 \%)\end{array}$ & $\begin{array}{c}95 \\
(33.6 \%)\end{array}$ & $\begin{array}{c}166 \\
(58.7 \%)\end{array}$ \\
\hline B6 & $\begin{array}{l}\text { I can talk to } \\
\text { my family } \\
\text { about my } \\
\text { problems. }\end{array}$ & $\begin{array}{c}11 \\
(3.9 \%)\end{array}$ & $\begin{array}{c}36 \\
(12.7 \%)\end{array}$ & $\begin{array}{c}113 \\
(39.9 \%)\end{array}$ & $\begin{array}{c}123 \\
(43.5 \%)\end{array}$ \\
\hline B9 & $\begin{array}{l}\text { My family is } \\
\text { ready to } \\
\text { help me } \\
\text { make } \\
\text { decisions. }\end{array}$ & $\begin{array}{c}8 \\
(2.8 \%)\end{array}$ & $\begin{array}{c}20 \\
(7.1 \%)\end{array}$ & $\begin{array}{c}123 \\
(43.5 \%)\end{array}$ & $\begin{array}{c}132 \\
(46.6 \%)\end{array}$ \\
\hline B12 & $\begin{array}{l}\text { My family is } \\
\text { giving their }\end{array}$ & $\begin{array}{c}6 \\
(2.1 \%)\end{array}$ & $\begin{array}{c}26 \\
(9.2 \%)\end{array}$ & $\begin{array}{c}105 \\
(37.1 \%)\end{array}$ & $\begin{array}{c}146 \\
(51.6 \%)\end{array}$ \\
\hline
\end{tabular}




\begin{tabular}{|c|c|c|c|c|c|}
\hline & $\begin{array}{l}\text { best to help } \\
\text { me. }\end{array}$ & & & & \\
\hline & $\begin{array}{c}\text { Domain: } \\
\text { Support } \\
\text { availability }\end{array}$ & & & & \\
\hline B1 & $\begin{array}{l}\text { I always } \\
\text { have } \\
\text { someone } \\
\text { with me in } \\
\text { time of } \\
\text { need. }\end{array}$ & $\begin{array}{c}4 \\
(1.4 \%)\end{array}$ & $\begin{array}{c}16 \\
(5.7 \%)\end{array}$ & $\begin{array}{c}106 \\
(37.5 \%)\end{array}$ & $\begin{array}{c}157 \\
(55.5 \%)\end{array}$ \\
\hline B3 & $\begin{array}{l}\text { I have } \\
\text { someone } \\
\text { with whom } \\
\text { I am } \\
\text { comfortable } \\
\text { being. }\end{array}$ & $\begin{array}{c}4 \\
(1.4 \%)\end{array}$ & $\begin{array}{c}15 \\
(5.3 \%)\end{array}$ & $\begin{array}{c}100 \\
(35.3 \%)\end{array}$ & $\begin{array}{c}164 \\
(58.0 \%)\end{array}$ \\
\hline B11 & $\begin{array}{l}\text { I have } \\
\text { someone } \\
\text { special with } \\
\text { whom I can } \\
\text { share my } \\
\text { joys and } \\
\text { sorrows. }\end{array}$ & $\begin{array}{c}10 \\
(3.5 \%)\end{array}$ & $\begin{array}{c}32 \\
(11.3 \%)\end{array}$ & $\begin{array}{c}99 \\
(35.0 \%)\end{array}$ & $\begin{array}{c}142 \\
(50.2 \%)\end{array}$ \\
\hline B8 & $\begin{array}{l}\text { There is } \\
\text { someone } \\
\text { who cares } \\
\text { about my } \\
\text { feelings. }\end{array}$ & $\begin{array}{c}8 \\
(2.8 \%)\end{array}$ & $\begin{array}{c}26 \\
(9.2 \%)\end{array}$ & $\begin{array}{c}115 \\
(40.6 \%)\end{array}$ & $\begin{array}{c}134 \\
(47.3 \%)\end{array}$ \\
\hline
\end{tabular}

The following analysis was on role conflict constructs. Working women often reported conflicts between work and family. Therefore, the researchers performed factor analysis on the data to determine the domain for this construct. There are three (3) domains that can be examined, namely, mother vs employee conflict, wife vs employee conflict and work-related stress. Items for the mother vs career conflict domain are C8, $\mathrm{C} 9, \mathrm{C} 12, \mathrm{C} 13, \mathrm{C} 14$, and C16. Besides that, wife vs employee conflict is determined by items C4, C6, C7, C10, C11, and C15. Then, the work-related stress domain is represented by items $\mathrm{C} 1, \mathrm{C} 2, \mathrm{C} 3$, and $\mathrm{C} 5$. All items were developed to describe the rate of role conflict experienced by respondents.

An analysis of the first domain, mother vs employee conflict, revealed surprising results. Many respondents admitted that they experienced this conflict and were deeply affected by it. Some examples of the items for this conflict are: "I cannot be the best mother because of the workload in the workplace", "I can no longer balance the time between work and family". Many of them said they could not be the best mothers (from their perspectives) because of the workload in their workplaces (28.3\%). While 
the percentage is not very high, this perception needs to be addressed; otherwise, it will jeopardize the family institution. Some respondents also admitted that they could not balance the time between work and family. Most of the time, they have to sacrifice their families over their careers. This fact is proven by item $\mathrm{C} 12$ which concerns the inability to build a good relationship with their children due to time constraints $(23.4 \%)$. Respondents also reported not having enough time to rest due to demands at work and home (40.3\%) (C14). Proper attention should be given to this factor since it indicates the emotional well-being level of working women. This finding was further reinforced by item C16, which stated that the respondents were aware that their children received less attention from them.

The wife vs employee domain did not show any critical result compared to the mother vs employee domain. About $15.9 \%$ of the respondents agreed that relationships with their husbands were problematic because of their work commitment (C4). Respondents also reported that they and their husbands often quarrelled because of work-related issues (14.2\%). They also admitted that their husbands often argued about the time they spent with the family. A small number of respondents said that their marriages were problematic due to their busy work schedules (7.5\%). This finding suggests that role conflict has affected their role as mothers more than their role as wives. Thus, children are the ones who are more affected due to their mothers' busy work schedules and role conflicts faced by those women.

The last domain examined from factor analysis is career stress. That domain is measured based on the degrees of fatigue, workload, and emotional instability. Many respondents (61.4\%) expressed that they often came home feeling very tired. Fatigue could be a factor that prevented them from spending quality time with their families. A total of $42.1 \%$ also reported that their heavy workload took away the time they should spend with their families. Even more worrying, about $33.3 \%$ of the respondents admitted that they became irritable at home due to work-related stress (refer to Table 2). This finding suggests that work-related stress has disrupted their emotions and roles as wives and mothers at home. Respondents experienced symptoms of emotional disturbances that could become more chronic if left untreated. Thus, all these symptoms and indicators need to be addressed immediately to help working women achieve emotional well-being. 


\begin{tabular}{|c|c|c|c|c|c|}
\hline No & Items & $\begin{array}{l}\text { Strongly } \\
\text { disagree }\end{array}$ & Disagree & Agree & $\begin{array}{l}\text { Strongly } \\
\text { agree }\end{array}$ \\
\hline C4 & $\begin{array}{l}\text { Domain: Wife vs } \\
\text { employee conflict } \\
\text { My relationship } \\
\text { with my husband } \\
\text { has always been } \\
\text { problematic } \\
\text { because of my } \\
\text { work } \\
\text { commitments. }\end{array}$ & $\begin{array}{c}109 \\
(38.5 \%)\end{array}$ & $\begin{array}{c}129 \\
(45.6 \%)\end{array}$ & $\begin{array}{c}37 \\
(13.1 \%)\end{array}$ & $8(2.8 \%)$ \\
\hline C15 & $\begin{array}{l}\text { I prioritise my } \\
\text { career over my } \\
\text { family. }\end{array}$ & $\begin{array}{c}131 \\
(46.3 \%)\end{array}$ & $\begin{array}{c}127 \\
(44.9 \%)\end{array}$ & $\begin{array}{c}19 \\
(6.7 \%)\end{array}$ & $\begin{array}{c}6 \\
(2.1 \%)\end{array}$ \\
\hline C6 & $\begin{array}{l}\text { My husband and I } \\
\text { often quarrel over } \\
\text { career-related } \\
\text { issues. }\end{array}$ & $\begin{array}{c}129 \\
(45.6 \%)\end{array}$ & $\begin{array}{c}114 \\
(40.3 \%)\end{array}$ & $\begin{array}{c}31 \\
(11 \%)\end{array}$ & $9(3.2 \%)$ \\
\hline C7 & $\begin{array}{l}\text { My husband often } \\
\text { argues about the } \\
\text { time I spend with } \\
\text { the family. }\end{array}$ & $\begin{array}{c}142 \\
(50.2 \%)\end{array}$ & $\begin{array}{c}101 \\
(35.7 \%)\end{array}$ & $\begin{array}{c}33 \\
(11.7 \%)\end{array}$ & $7(2.5 \%)$ \\
\hline $\mathrm{C} 10$ & $\begin{array}{l}\text { My husband does } \\
\text { not support my } \\
\text { career. }\end{array}$ & $\begin{array}{c}166 \\
(58.7 \%)\end{array}$ & $\begin{array}{c}93 \\
(32.9 \%)\end{array}$ & $\begin{array}{c}16 \\
(5.7 \%)\end{array}$ & $8(2.8 \%)$ \\
\hline $\mathrm{C} 11$ & $\begin{array}{l}\text { My marriage is in } \\
\text { trouble because of } \\
\text { my busy work } \\
\text { schedule. }\end{array}$ & $\begin{array}{c}170 \\
(60.1 \%)\end{array}$ & $\begin{array}{c}92 \\
(32.5 \%)\end{array}$ & $\begin{array}{c}16 \\
(5.7 \%)\end{array}$ & $5(1.8 \%)$ \\
\hline C8 & $\begin{array}{l}\text { I cannot be the } \\
\text { best mother due to } \\
\text { my workload. }\end{array}$ & $\begin{array}{c}101 \\
(35.7 \%)\end{array}$ & $\begin{array}{c}102 \\
(36.0 \%)\end{array}$ & $\begin{array}{c}62 \\
(21.9 \%)\end{array}$ & $\begin{array}{c}18 \\
(6.4 \%)\end{array}$ \\
\hline C9 & $\begin{array}{l}\text { I can no longer } \\
\text { balance the time } \\
\text { between work and } \\
\text { family. }\end{array}$ & $\begin{array}{c}105 \\
(37.1 \%)\end{array}$ & $\begin{array}{c}119 \\
(42.0 \%)\end{array}$ & $\begin{array}{c}47 \\
(16.6 \%)\end{array}$ & $\begin{array}{c}12 \\
(4.2 \%)\end{array}$ \\
\hline C12 & $\begin{array}{l}\text { I am unable to } \\
\text { build a good } \\
\text { relationship with } \\
\text { my child due to } \\
\text { time constraints. }\end{array}$ & $\begin{array}{c}124 \\
(43.8 \%)\end{array}$ & $\begin{array}{c}93 \\
(32.9 \%)\end{array}$ & $\begin{array}{c}48 \\
(17 \%)\end{array}$ & $\begin{array}{c}18 \\
(6.4 \%)\end{array}$ \\
\hline $\mathrm{C} 13$ & $\begin{array}{l}\text { The welfare of my } \\
\text { children is } \\
\text { neglected every } \\
\text { time I work out of } \\
\text { town. }\end{array}$ & $\begin{array}{c}149 \\
(52.7 \%)\end{array}$ & $\begin{array}{c}96 \\
(33.9 \%)\end{array}$ & $\begin{array}{c}27 \\
(9.5 \%)\end{array}$ & $\begin{array}{c}11 \\
(3.9 \%)\end{array}$ \\
\hline
\end{tabular}


Table 2

\begin{tabular}{|c|c|c|c|c|c|}
\hline & $\begin{array}{l}\text { I do not have the } \\
\text { time to rest }\end{array}$ & $\begin{array}{c}72 \\
(25.4 \%)\end{array}$ & $\begin{array}{c}97 \\
(34.3 \%)\end{array}$ & $\begin{array}{c}83 \\
(29.3 \%)\end{array}$ & $\begin{array}{c}31 \\
(11 \%)\end{array}$ \\
\hline C14 & $\begin{array}{l}\text { because I have to } \\
\text { meet the demands } \\
\text { at work and home. }\end{array}$ & & & & \\
\hline \multirow{3}{*}{ C16 } & I am aware that my & 85 & 104 & 72 & 22 \\
\hline & $\begin{array}{l}\text { child is getting less } \\
\text { attention from me. }\end{array}$ & $(30 \%)$ & $(36.7 \%)$ & $(25.4 \%)$ & $(7.8 \%)$ \\
\hline & $\begin{array}{l}\text { Domain: Work- } \\
\text { related stress }\end{array}$ & & & & \\
\hline & $\begin{array}{l}\text { My work schedule } \\
\text { often clashes with }\end{array}$ & 49 & 124 & 79 & 31 \\
\hline$C 1$ & $\begin{array}{l}\text { my planned } \\
\text { vacation. }\end{array}$ & $(17.3 \%)$ & $(43.8 \%)$ & $(27.9 \%)$ & $(11 \%)$ \\
\hline C2 & $\begin{array}{l}\text { I always come } \\
\text { home feeling very } \\
\text { tired. }\end{array}$ & $\begin{array}{c}18 \\
(6.4 \%)\end{array}$ & $\begin{array}{c}90 \\
(31.8 \%)\end{array}$ & $\begin{array}{c}104 \\
(36.3 \%)\end{array}$ & $\begin{array}{c}71 \\
(25.1 \%)\end{array}$ \\
\hline C3 & $\begin{array}{l}\text { I have a heavy } \\
\text { workload that } \\
\text { interferes with my }\end{array}$ & 32 & 132 & 76 & 43 \\
\hline & $\begin{array}{l}\text { time with the } \\
\text { family. }\end{array}$ & (11.3\%) & (46.6\%) & (26.9\%) & (15.2\%) \\
\hline C5 & $\begin{array}{l}\text { I am prone to get } \\
\text { irritated at home } \\
\text { due to work- } \\
\text { related stress. }\end{array}$ & $\begin{array}{c}72 \\
(25.4 \%)\end{array}$ & $\begin{array}{c}117 \\
(41.3 \%)\end{array}$ & $\begin{array}{c}63 \\
(22.3 \%)\end{array}$ & $\begin{array}{c}31 \\
(11 \%)\end{array}$ \\
\hline
\end{tabular}

Descriptive analysis of role conflict

\section{Discussion}

To ensure emotional well-being among working women, they need to get more social support and less role conflict. Social support should be provided by spouses, children, friends, and employers. Husbands should give their best in fulfilling their responsibilities at home by not letting their wives manage all the household chores alone. This type of role conflict will cause working women to experience depression, burnout, and lack of rest and, in turn, disrupt their emotional well-being.

Zakaria, Ebrahim and Rahmat (2020) have also explored the support received and desired by working women in Selangor. Eleven informants were selected to participate in a study conducted through an in-depth interviewing technique. Findings show that informants need social support in terms of emotions, childcare, information, networking and finance to safeguard their emotional well-being. Often, women try to gain emotional support by expressing their feelings and sharing their problems with close friends. The main problems that are often shared are those related to work and family. In terms of childcare support, these working women will feel calm when their children are taken care of by reliable persons such as husbands, family members or caregivers. Even when they are busy working, the welfare of their children will not be neglected at all. 
Informational support, including advice from their husbands or those who are more knowledgeable, is also needed in helping to solve the problems they are experiencing. Social networking support is related to the aid they receive to resolve issues in the workplace. Besides that, those working women still need financial support, although they have their sources of income. However, not all informants received financial support. This information is based on their reports that their husbands are unemployed, neglecting responsibilities, and some of those men even think their wives can support themselves. This issue highlights a situation that contradicts the teachings of the religion. As the head of the family, a husband bears the responsibility to look after his family members (Aun \& Mohd, 2016).

The results of this study are also consistent with research conducted by Hamzah, Mustari and Basiron (2014) on the distinguished women holding JUSA grade positions in the public sector management and professional group. The study has identified individual support as the factor determining the success of working and married women. Furthermore, the study has also identified the characteristics and roles of husbands, children, employers and colleagues concerning women's career development. In addition to collecting data from in-depth interviews, the researchers have also analysed documents from books on Islamic law, journals, working papers, and documents provided by the participants in the study. These multi-case studies were conducted at different locations and times involving various distinguished women with similar characteristics.

The study also found that working and married women needed support from individuals around them such as husbands, colleagues, parents, employers, maids, children and caregivers. Each of these individuals plays a role in providing social support through various means. Support from the husband is needed in sharing the responsibility of caring for and managing their children at home, motivating the wife, supporting the wife's career, and creating a harmonious atmosphere. Husbands also need to understand better the fatigue and stress experienced by their wives who work to ease the economic burden of the family (Al-Ghazali, 2004).

Also, employers need to be caring and understanding because this attitude will help reduce the conflict faced by working and married women (Ismail, 2011). Women with marital problems and role conflict issues will often be absent from work, make mistakes, lack concentration and fall sick (Kadir, 2009). Therefore, to provide emotional support to these working women, co-workers need to help each other by advising and listening to their problems. Kadir (2009) stated that bad relationships with colleagues could be stressful. This kind of stress can trigger other types of mental health disorders if left uncontrolled and untreated.

Working women will always face role conflicts if they do not receive any cooperation and assistance in managing the family. Women with teenage children can expect their kids to help with household chores. Teach the children the responsibility of doing household chores from an early age to familiarize them with it. These children need to be independent and capable of taking care of their own needs and doing household chores suitable for their ages and abilities. It will immensely relieve the workload of working mothers at home, as stipulated by the religion (Shalaby, 2001). Overall, everyone in the social sphere of working women has different roles to play in helping to alleviate the burden and role conflict faced by them. The support they receive from all those individuals will also help them attain emotional well-being. 


\section{Conclusion}

In brief, the issue of role conflict needs to be taken seriously by all parties. It is not easy to strike a balance in all the roles held by working women. Continuous role conflict can undermine women's mental health, decrease the quality of family relationships, and negatively impact children's development. Employers and supervisors should be sensitive to this issue. Although their female employees are highly committed, dedicated, and trustworthy in carrying out their duties and responsibilities, they should not continuously be burdened by additional workload or given work instructions after office hours or during weekends.

Work plans and schedules should be prepared in advance so that working women can plan their holidays and breaks. Working women also need some flexibility when faced with family problems and issues such as caring for bedridden husbands, taking their children for follow-up treatment, or suffering from chronic illnesses. They can keep on optimally contributing if employers understand their constraints and difficulties. Organizations with female employees should also encourage a culture of open discussion and tolerance.

\section{Acknowledgement}

I would like to extend my deepest gratitude to Ministry of Higher Education Malaysia and UKM for supporting this research. The research code is FRGS/1/2020/SSO/UKM/02/29.

\section{References}

Ahrens, C. J. C., \& Ryff, C. D. (2006). Multiple roles and well-being: Sociodemographic and psychological moderators. Sex Roles, 55(11-12), 801-815. https://doi.org/10.1007/s11199-006-9134-8

Alex, R. A. (2015). Stress tolerance and adjustment among working and non-working women: A comparative study. Journal of Research, 6(1), 7-12. https://doi.org/10.5958/09761748.2015.00002.8

Al-Ghazali, Z. (2004). Nasihat Untuk Wanita. Jabatan Kemajuan Islam Malaysia.

Aun, N. S. M., \& Mohd, R. H. (2016). Informal caregiving: Empowering social support programs by employers. Akademika, 86(1), 3-9. http://dx.doi.org/10.17576/akad-2016-8601-01

Kadir, H. A. (2009). Kaunseling di tempat Kerja. Penerbit UTM PRESS

Hamzah, N., Mustari, M. I., \& Basiron, B. (2014). Faktor Sokongan Individu Terhadap Kecemerlangan Wanita Bekerjaya dan Berumah Tangga. Sains Humanika, 67(1). https://doi.org/10.11113/sh.v67n1.125

Hays, S. (1998). The Cultural Contradictions of Motherhood. UK. Yale University Press.

Ibrahim, S. H., \& Ramli, Z. (2021). Konflik kerja-keluarga dalam kalangan penjawat awam wanita. Geografia-Malaysian Journal of Society and Space, 17(1), 140-154. https://doi.org/10.17576/geo-2021-1701-11

Ismail, A. (2011). Pembentukan Keluarga Berkualiti dalam kalangan Wanita Bekerjaya Menurut Islam: Kajian Kes di Putrajaya [Tesis Ijazah Doktor Falsafah, Universiti Sains Malaysia].

Jabatan Perangkaan Malaysia. (2020). Statistik Pemerkasaan Wanita dalam Domain Terpilih. Pusat Pentadbiran Kerajaan Persekutuan, Putrajaya.

Jabatan Perangkaan Malaysia. (2021). Siaran Akhbar. Statistik Utama Tenaga Buruh di Malaysia, Februari 2021. https://www.dosm.gov.my/v1/index. 
Janzen, B. L., \& Muhajarine, N. (2003). Social role occupancy, gender, income inadequacy, life stage and health: A longitudinal study of employed Canadian men and women. Social Science \& Medicine, 57, 1491-1503. https://doi.org/10.1016/S0277-9536 (02)00544-0

Lapierre-Adamcyk, E., Marcilgratton, N., \& Le Bourdais, C. (2006). “A Balancing Act: Parents' Work Arrangements and Family Time." In K. McQuillan and Z. R. Ravanera (Eds.), Canada's Changing Families: Implications for Individuals and Society. (pp. 49-75). University of Toronto Press.

Luffman, J. (2006). The core-age labour force. Perspectives on Labour and Income, 7(9), 5-11. Noor, N. M. (1999). Roles and women's well-being: Some preliminary findings from Malaysia. Sex roles, 41(3), 123-145. https://doi.org/10.1023/A:1018846010541

Perangkaan Tenaga Buruh (2006). Laporan Penyiasatan Tenaga Buruh, 2006, 2007, 2008 dan 2009. Jabatan Perangkaan Malaysia. http://www.rurallink.gov.my/wp

Shalaby, A. (2001). Kehidupan Sosial Dalam Pemikiran Islam. Singapura. Pustaka Nasional.

Statistik Utama Tenaga Buruh (2016). Statistik pekerjaan dan pemburuhan. Kementerian Sumber Manusia. https://www.dosm.gov.my/v1/index.php

Sumra, M. K., \& Schillaci, M. A. (2015). Stress and the Multiple-Role Woman: Taking a Closer Look at the "Superwoman". PloS One, 10 (3), 1-24.

https://doi.org/10.1371/journal.pone.0120952

Tézli, A., \& Gauthier, A. (2009). Balancing Work and Family in Canada: An Empirical Examination of Conceptualizations and Measurements. The Canadian Journal of Sociology / Cahiers Canadiens De Sociologie, 34(2), 433-461. http://www.jstor.org/stable/canajsocicahican.34.2.433.

Williams, D. R., Larson, D. B., Buckler, R. E., Heckmann, R. C., \& Pyle, C. M. (1991). Religion and psychological distress in a community sample. Social Science and Medicine, 32,

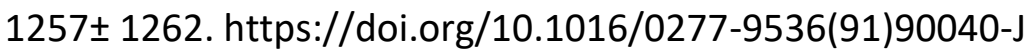

Zakaria, S. M., Ebrahim, M. I., \& Rahmat, H. (2020). Boleh tolong saya? Meneroka sokongan sosial yang diperlukan oleh wanita bekerjaya bagi meningkatkan kesejahteraan emosi. e-Bangi, 17(3), 1-13.

Zakaria, S. M., ljon, R., Shaharuddin, W. Y. W., Nawi, N. H. M., Yusuff, N. A., \& Yin, S. S. (2017). Kepuasan Kerjaya Dan Sokongan Sosial Sebagai Indikator Kepuasan Hidup Wanita Bekerjaya Pertengahan Usia Di Kelantan. http://hdl.handle.net/123456789/616

Zimet, G. D., Dahlem, N. W., Zimet S. G., \& Farley, G. K. (1988). The Multidimensional Scale of Perceived Social Support. Journal of Personality Assessment, 52, 30-41. 